\title{
Effects of Dietary Protein Level and Betaine Supplementation on Nutrient Digestibility and Performance of Japanese Quails
}

\section{-Author(s)}

\section{Ratriyanto $A^{\prime}$}

Indreswari $\mathrm{R}^{\prime}$

Nuhriawangsa AMPI

Department of Animal Science, Faculty of Agriculture, Sebelas Maret University, J. Ir. Sutami 36A, Surakarta, Indonesia 57126

Note: Part of the data presented here were presented at the 6th International Seminar on Tropical Animal Production in Yogyakarta, Indonesia (ISTAP 2015).

\section{-Mail Address}

Corresponding author e-mail address Adi Ratriyanto

Department of Animal Science, Faculty of Agriculture, Sebelas Maret University, Jl. Ir.

Sutami 36A, Surakarta, Indonesia 57126

Tel: $\quad$ +62-271-637457

Email: ratriyanto@staff.uns.ac.id

\section{- Keywords}

Betaine, digestibility, laying Japanese quails, performance, protein.

\section{ABSTRACT}

This study investigated the effects of dietary protein levels and betaine supplementation on nutrient digestibility and performance of Japanese quails. In total, 765 Japanese quails were randomly assigned to a $3 \times 3$ factorial arrangement, with five replicates of 17 quails each. Three basal diets were formulated to contain three crude protein levels (16.5, 18.0, and $19.5 \%$ ). Each protein level was supplemented with $0,0.06$, and $0.12 \%$ betaine. The diet with $16.5 \%$ dietary crude protein with no betaine supplementation resulted in the lowest crude fiber digestibility, while the $18.0 \%$ CP diet supplemented with $0.12 \%$ betaine generated the highest crude fiber digestibility $(p<0.05)$. The diets with 18.0 and $19.5 \%$ crude protein increased crude fiber digestibility, but reduced ether extract digestibility $(p<0.01)$. Moreover, betaine supplementation increased dry matter, crude protein, crude fiber, and crude ash $(p<0.01)$ digestibility and tended to increase ether extract digestibility $(p=0.09)$. The increase in egg weight for the 18.0 and $19.5 \%$ protein diets was correlated with a decrease in feed conversion ratio $(p<0.05)$. However, feed intake and egg production were not affected by protein levels. Betaine supplementation enhanced all performance variables $(p<0.01)$. The diets with 18.0 and $19.5 \%$ crude protein resulted in heavier yolks and eggshells than the $16.5 \%$ crude protein diet $(p<0.05)$, whereas betaine supplementation increased yolk, albumen, and eggshell weight $(p<0.01)$. The 18.0 and $19.5 \%$ protein diets produced similar responses in most evaluated parameters. Laying Japanese quails can be fed diets with $18.0 \%$ crude protein. Moreover, betaine supplementation provided several benefits, and particularly improved nutrient digestibility, performance, and egg quality.

\section{INTRODUCTION}

Layers are susceptible to heat stress because egg formation results in a high level of metabolic heat production (Blem, 2000). Moreover, the high ambient temperature in the tropics may limit protein synthesis, negatively affecting poultry production (Rashid et al., 2012). Proteinrich diets do not have a positive impact on poultry performance in hot climates and may even depress performance due to the high heat increment of protein digestion (Daghir, 2009). Although many studies have been performed to evaluate the effects of dietary crude protein $(\mathrm{CP})$ in layers, the responses have been inconsistent among studies, possibly due to differences in experimental conditions, bird strains and age, laying period, and parameters evaluated (Li et al., 2013; Ding et al., 2016). Previous studies demonstrated that dietary CP influences laying performance and egg quality (Nahashon et al., 2007; Gunawardana et al., 2008; Li et al., 2013). Under tropical conditions, Musa et al. (2008) recommended 18\% CP for laying quails, which is lower than the $20 \%$ recommended by the NRC (1994). Garcia et al. (2005) observed 
that, in quails, increasing dietary CP from $16 \%$ to $18 \%$ improved egg production and feed conversion ratio, while increasing dietary CP to $20 \%$ did not result in the further performance improvements. According to Junqueira et al. (2006), for brown hens, feeding with $16 \%$ CP was adequate and resulted in better performance and egg quality than $18 \%$ and $20 \%$ CP.

Betaine is a trimethyl derivative of the amino acid glycine. It is a methyl group donor, donating its labile methyl group $\left(\mathrm{CH}_{3}\right)$, and plays an important role in the metabolism of protein and energy (MetzlerZebeli et al., 2009; Ratriyanto et al., 2009a). Because poultry cannot synthesize the methyl group, it must be supplied in their diet. Unlike other methyl group donors, such as choline and methionine, betaine can act directly as a methyl group donor. The methyl groups of choline become available when choline is oxidized to betaine, while methionine must be converted to S-adenosylmethionine to donate its methyl group (Ratriyanto et al., 2009a). Betaine has the potential to substitute for some part of methionine in the diet by providing a methyl group during the conversion of homocysteine to methionine (Metzler-Zebeli et al., 2009). Consequently, betaine may improve methionine availability for protein synthesis, thus achieving optimal performance (Rao et al., 2011). Moreover, due to its osmotic properties, betaine has the potential to improve nutrient digestibility by supporting the growth and survival of intestinal cells, as well as intestinal microbes (Kettunen et al., 2001; Ratriyanto et al., 2009a). It has been shown that betaine supplementation alters the microbial population of the digestive tract of poultry (Kettunen et al., 1999). Dietary betaine may protect intestinal cells and intestinal microbes from osmotic variation along the digestive tract (Ratriyanto et al., 2009a).

Furthermore, there are only few studies evaluating dietary CP levels and betaine supplementation in relation to nutrient digestibility in poultry, particularly in laying quails, even though dietary CP levels or betaine supplementation affect nutrient digestibility in quails (Li et al., 2011; Ratriyanto et al., 2012). Therefore, the objective of this study was to determine the effects of dietary CP levels and betaine supplementation on nutrient digestibility and performance in quails.

\section{MATERIAL AND METHODS}

In total, 765 42-day-old female Japanese quails (Coturnix coturnix japonica), with an average body weight of $126.34 \pm 7.29 \mathrm{~g}$, were used in the study. The birds were randomly distributed according to a completely randomized experimental design in a 3 $\times 3$ factorial arrangement: CP levels (16.5, 18.0, and $19.5 \%)$ and betaine supplementation $(0,0.06$, and $0.12 \%)$. Each treatment included five replicates of 17 quails each.

The birds were reared in 45 colony battery cages $(75 \times 50 \mathrm{~cm}$, one cage per replicate). A uniform managemental practice was applied to all the experimental groups.

The three basal diets were formulated to contain the same amount of metabolizable energy: $2,800 \mathrm{kcal} /$ $\mathrm{kg}$ (Table 1). Betaine (anhydrous betaine 96\%) was supplemented in the basal diets at the expense of corn, according to the procedure of Ratriyanto et al. (2009b).

Table 1 - Ingredient composition (\%) and calculated nutrient content of the basal diets.

\begin{tabular}{lccc}
\hline Ingredients & \multicolumn{3}{c}{ Protein Levels } \\
\cline { 2 - 4 } & $16.5 \%$ & $18.0 \%$ & $19.5 \%$ \\
\hline Yellow corn & 45.63 & 45.50 & 44.12 \\
\hline Rice bran & 21.43 & 18.04 & 15.00 \\
Soybean meal & 18.15 & 20.20 & 24.15 \\
Fishmeal & 5.00 & 6.75 & 7.00 \\
Coconut oil & 1.28 & 1.37 & 1.80 \\
\hline LL-methionine & 0.08 & 0.05 & 0.03 \\
L-lysine HCl & 0.18 & 0.09 & 0.00 \\
Dicalcium phosphate & 1.65 & 1.50 & 1.40 \\
Limestone & 5.90 & 5.80 & 5.80 \\
Premix* & 0.35 & 0.35 & 0.35 \\
NaCl & 0.35 & 0.35 & 0.35 \\
\hline
\end{tabular}

Nutrient contents

\begin{tabular}{lccc}
\hline Metabolizable energy $(\mathrm{kcal} / \mathrm{kg})$ & 2800.50 & 2800.20 & 2800.10 \\
\hline Crude protein (\%) & 16.50 & 18.01 & 19.51 \\
\hline Ether extracts (\%) & 5.09 & 4.85 & 4.60 \\
Crude fiber (\%) & 4.58 & 4.24 & 4.03 \\
Crude ash (\%) & 5.00 & 5.36 & 5.49 \\
Calcium (\%) & 3.40 & 3.41 & 3.40 \\
Available phosphorus (\%) & 0.61 & 0.63 & 0.62 \\
Lysine (\%) & 1.13 & 1.14 & 1.14 \\
Methionine (\%) & 0.41 & 0.41 & 0.41 \\
Cystine (\%) & 0.29 & 0.30 & 0.31 \\
Methionine+cystine (\%) & 0.70 & 0.71 & 0.72 \\
\hline
\end{tabular}

* The premix supplied the following per kilogram diets: 42,000 IU vitamin A; 7,000 IU vitamin $\mathrm{D}_{3} ; 28 \mathrm{mg}$ vitamin $\mathrm{E} ; 7 \mathrm{mg}$ vitamin $\mathrm{K} ; 7 \mathrm{mg}$ vitamin $\mathrm{B} 1 ; 18 \mathrm{mg}$ vitamin $\mathrm{B} 2 ; 2 \mathrm{mg}$ vitamin B6; 42 mg vitamin B12; 88 mg vitamin C; 21 mg calcium D-pantothenate; 140 mg niacin; 35 mg choline chloride; 420 mg manganese; 70 mg iron; 0.7 mg iodine; $350 \mathrm{mg}$ zinc; $0.7 \mathrm{mg}$ cobalt; $14 \mathrm{mg}$ copper, $35 \mathrm{mg}$ antioxidant (santoquin).

The birds were housed under natural temperature conditions, with an average ambient temperature during experiment at $25.4^{\circ} \mathrm{C}$ in the morning, $32.9^{\circ} \mathrm{C}$ in the afternoon, and $28.7^{\circ} \mathrm{C}$ in the evening. During the pre-experimental period (42 days until $50 \%$ hen day average - HDA), the birds were fed the same diet, which contained $18 \%$ CP. The dietary treatments 
started to be applied after egg production reached 50\% HDA. Water and feed were provided ad libitum. The treatment diets were fed for two periods of 28 days each ( $2 \times 28$ days). Feed intake, egg production, and egg weight were recorded daily. Feed conversion ratio (FCR) was calculated as the ratio of feed intake per egg mass (Junqueira et al., 2006). Protein efficiency ratio (PER) and energy efficiency ratio (EER) were also calculated for each experimental period. PER was calculated as grams of egg mass per gram of protein intake, and EER was calculated as grams of egg mass×100/total ME intake (Suprijatna et al., 2009). Physical egg quality was assessed during the last three days of each period (days 26, 27, and 28). In total, 405 eggs from each period (nine eggs per replicate) were randomly collected to evaluate yolk weight, albumen weight, and eggshell weight and thickness. The eggs were weighed and cracked, and the egg components were weighed thereafter. Eggshell thickness was measured with a digital micrometer $(0-25 \times 0.001$ $\mathrm{mm})$.

At the end of experiment, 90 birds (two per replicate) were randomly selected to determine nutrient digestibility. The digestibility trial was performed over a 5-day total excreta collection, following the procedure proposed by Ratriyanto et al. (2014a). During the collection period, the excreta were periodically spread with $0.2 \mathrm{~N} \mathrm{H}_{2} \mathrm{SO}_{4}$ to minimize further bacterial fermentation. The excreta collected during the 5 days were dried under the sun. The samples of excreta for the various diets were milled through a $0.5 \mathrm{~mm}$ mesh screen prior to analysis. Excreta CP content was determined by the Kjeldahl method, while dry matter $(D M)$, ether extract (EE), crude fiber (CF), and crude ash (CA) analyses were performed as outlined by the AOAC (1990). The nutrient digestibility coefficients were calculated according to Emamzadeh \& Yaghobfar (2009).

The data were checked for outliers and tested to ensure the homogeneity of variances (Bartlett test). Then, the data were submitted to analysis of variance using the R statistic (R Core Team, 2015). Statistically different means were compared via Duncan's multiplerange test at $5 \%$ probability.

\section{RESULTS AND DISCUSSION}

\section{Nutrient Digestibility}

There was no influence of the interaction between protein levels and betaine supplementation on nutrient digestibility (Table 2), except for CF. The16.5\% CP diet without betaine supplementation resulted in lower $C F$ digestibility than the other dietary treatments $(p<0.05)$. Also, for the three CP levels, $0.12 \%$ betaine supplementation increased CF digestibility, which ranged between 12.87 and $26.89 \%$, as compared with the non-supplemented diets $(p<0.05)$. Regardless of the CP level in the diets, these findings indicate that betaine supplementation improved CF digestibility possibly due to stimulation of microbial fermentation in the digestive tract (Ratriyanto et al., 2014a).

Dietary CP levels did not affect the digestibility of DM, CP, CA, or nitrogen free extracts (NFE). This result is in agreement with Li et al. (2011), who did not find any effect of dietary CP levels (17.75 or $19.95 \%$ CP) on organic matter (OM) digestibility in yellow quails. Feeding 17 and 20\% CP did not affect CP digestibility in broilers either (Faria Filho et al., 2007). In Japanese quails, during the rearing period, Omidiwura et al. (2016) did not find any effect of CP levels on the digestibility of DM and CP.

In the present experiment, dietary 18.0 and $19.5 \%$ CP decreased $(p<0.01)$ EE digestibility by 7.10 and $7.56 \%$, respectively, as compared with $16.5 \% \mathrm{CP}$, indicating better $\mathrm{EE}$ utilization at lower dietary $\mathrm{CP}$ levels. According to Rosebrough et al. (1999), dietary CP levels modulate the metabolic effects of dietary fat, as increasing dietary CP reduces lipogenesis and the levels of precursors of fat synthesis, which may explain the decrease in the digestibility coefficient of EE with increasing dietary CP levels in the present experiment. Moreover, dietary 18.0 and $19.5 \% \mathrm{CP}$ improved $(p<0.01)$ CF digestibility by 7.12 and $6.45 \%$, respectively, as compared with $16.5 \% \mathrm{CP}$, indicating more efficient CF degradation and absorption (Faria Filho et al., 2007). This result was in agreement with the previous observation that CF digestibility increased as dietary CP increased (Ratriyanto et al., 2014a). In addition, according to Li et al. (2011), the effect of CP level on nutrient digestibility can be attributed to an imbalance between protein and energy in the diet.

The supplementation of 0.06 and $0.12 \%$ betaine improved DM, CP, CF, and CA digestibilities $(p<0.05)$ and tended to improve EE digestibility $(p=0.09)$, which is in agreement with previous studies with quails (Ratriyanto et al., 2012). Similarly, dietary betaine supplementation was also shown to improve the digestibility of CP (Ezzat et al., 2011; Attia et al., 2016) and EE in laying chickens (Ezzat et al., 2011). Moreover, studies with broilers have revealed that betaine improved DM (Ratriyanto et al., 2014a; Amerah \& Ravindran, 2015), OM (El-Husseiny et al., 2007), CP, 
CF (El-Husseiny et al., 2007; Ratriyanto et al., 2014a), $\mathrm{EE}$, and NFE digestibilities (El-Husseiny et al., 2007). These results indicate that betaine supplementation promotes better nutrient utilization, as confirmed by the improvement in production performance in the present experiment (Table 3).

There is growing evidence that betaine supplementation improves nutrient digestibility due to its osmoprotective properties, supporting intestinal cells and the growth of intestinal microbes (Ratriyanto et al., 2009a; Ratriyanto et al., 2010). Previous reports have shown that betaine decreased crypt:villus height ratio in broilers, which may partially explain the increased digestibility of nutrients (Kettunen et al., 2001; Ratriyanto et al., 2014b). Moreover, because poultry do not produce fiber-degrading enzymes, the improvement in CF digestibility indicates that betaine has the potential to stimulate the bacterial fermentation of dietary fiber (Ratriyanto et al., 2010; Ratriyanto 2014a). These results confirm previous observation that intestinal bacteria require compatible osmolytes, such as betaine (Ratriyanto et al., 2010). The higher CF digestibility due to betaine supplementation corresponded to higher CA digestibility. Previous studies have shown the interaction between fiber fermentation and mineral absorption (Ohta et al.,
1995; Aulrich \& Flachowsky, 1997). Obviously, the fiber fraction holds nutrients that can be released during fiber degradation (Aulrich \& Flachowsky, 1997). Higher mineral absorption, as indicated by improved CA digestibility, supports the previous observations that betaine reduces the osmolality of the digesta of chickens (Klasing et al., 2002; Hamidi et al., 2010).

\section{Production Performance}

There was no significant interaction between dietary CP levels and betaine supplementation levels for the evaluated performance parameters. Dietary $C P$ levels did not affect feed intake or egg production, but the 19.5\% CP diet improved feed conversion ratio $(p<0.05)$. These results are in agreement with those of Dos Santos et al. (2016), who did not find any significant effect on feed intake or egg production of quails fed 16 or $20 \%$ CP. In addition, previous observations in Japanese quails determined that increasing dietary CP from 17 to 20\% (Tuleun et al., 2013) or from 15 to $20 \%$ (Muhammad et al., 2016) did not affect egg production, but did improve feed conversion ratio. A recent study showed that increasing dietary CP from 18 to $24 \%$ did not affect egg production, egg weight, or feed conversion ratio in Japanese quails (Agboola et al., 2016). On the other hand, Azghadi et al. (2014) found

Table 2 - Nutrient digestibility in Japanese quails (\%) fed diets with varying levels of crude protein and betaine.

\begin{tabular}{|c|c|c|c|c|c|c|c|}
\hline Treatments & & Dry Matter & Crude Protein & Ether Extracts & Crude Fiber & Crude Ash & Nitrogen Free Extracts \\
\hline \multicolumn{8}{|c|}{ Interaction effects between protein (\%) and betaine (\%) } \\
\hline 16.5 & 0 & 70.14 & 71.80 & 89.65 & $27.46^{d}$ & 46.72 & 85.25 \\
\hline 16.5 & 0.06 & 73.31 & 73.05 & 90.25 & $33.18^{b c}$ & 52.91 & 81.32 \\
\hline 16.5 & 0.12 & 78.08 & 80.74 & 90.68 & $36.41^{\mathrm{ab}}$ & 61.92 & 81.14 \\
\hline 18.0 & 0 & 69.42 & 69.25 & 81.62 & $31.60^{c}$ & 49.26 & 82.82 \\
\hline 18.0 & 0.06 & 74.54 & 74.20 & 83.80 & $35.32^{\mathrm{abc}}$ & 54.97 & 82.03 \\
\hline 18.0 & 0.12 & 74.17 & 76.00 & 85.95 & $37.56^{a}$ & 61.73 & 80.43 \\
\hline 19.5 & 0 & 70.65 & 68.18 & 81.44 & $31.67 c$ & 50.76 & 82.78 \\
\hline 19.5 & 0.06 & 74.03 & 71.05 & 83.55 & $35.73^{\mathrm{abc}}$ & 55.17 & 84.06 \\
\hline 19.5 & 0.12 & 75.72 & 76.36 & 85.12 & $36.35^{\mathrm{ab}}$ & 60.70 & 83.18 \\
\hline SEM & & 0.41 & 0.26 & 0.31 & 0.51 & 0.63 & 0.67 \\
\hline$p$ value & & 0.52 & 0.87 & 0.72 & 0.03 & 0.65 & 0.18 \\
\hline \multicolumn{8}{|c|}{ Effects of protein (\%) } \\
\hline 16.5 & & 73.84 & 75.20 & $90.19^{a}$ & $32.35^{b}$ & 53.85 & 82.57 \\
\hline 18.0 & & 72.71 & 73.15 & $83.79^{b}$ & $34.83^{a}$ & 55.32 & 81.76 \\
\hline 19.5 & & 73.46 & 71.86 & $83.37^{b}$ & $34.58^{a}$ & 55.55 & 83.34 \\
\hline SEM & & 0.15 & 1.24 & 1.82 & 0.91 & 0.69 & 0.31 \\
\hline$p$ value & & 0.76 & 0.09 & $<0.01$ & $<0.01$ & 0.47 & 0.53 \\
\hline \multicolumn{8}{|c|}{ Effects of betaine (\%) } \\
\hline 0 & & $70.07^{b}$ & $69.74^{b}$ & 84.23 & $30.24^{c}$ & $48.91^{c}$ & 83.62 \\
\hline 0.06 & & $73.96^{a}$ & $72.77^{b}$ & 85.87 & $34.74^{b}$ & $54.35^{b}$ & 82.47 \\
\hline 0.12 & & $75.99^{a}$ & $77.70^{\mathrm{a}}$ & 87.25 & $36.77^{a}$ & $61.45^{a}$ & 81.58 \\
\hline SEM & & 1.74 & 1.49 & 0.87 & 1.23 & 1.15 & 0.59 \\
\hline$p$ value & & $<0.01$ & $<0.01$ & 0.09 & $<0.01$ & $<0.01$ & 0.26 \\
\hline
\end{tabular}

\footnotetext{
$a, b, c$ Means in the same column and treatment with no common superscript differ significantly $(p<0.05)$.
} 
that increasing dietary CP from 18 to $22 \%$ increased egg production, but did not affect feed intake, egg weight, or feed conversion ratio. In addition, Garcia et al. (2005) observed that feeding with 18\% CP resulted in the best performance of laying quails.

In the present study, dietary 18.0 and $19.5 \% \mathrm{CP}$ resulted in higher egg weight compared with $16.5 \%$ CP $(p<0.05)$, which may be attributed to the fact that birds fed 18.0 and $19.5 \%$ CP consumed more protein than those fed the $16.5 \%$ CP diet. It is wellestablished that protein is the main nutrient required for egg formation (Ding et al., 2016). Egg weight is highly correlated with daily CP intake because laying hens are not able to store large amounts of protein (Li et al., 2011). Moreover, feed intake and CP levels are important in controlling protein intake (Soares et al., 2003). The discrepancies in the results obtained by different studies may be due to differences in experimental conditions and diets.

The observed increase $(p<0.01)$ in egg mass in birds fed 18.0 and $19.5 \%$ CP compared with those fed a $16.5 \%$ CP diet may be due to higher egg weight, and not to higher egg production, which was not significantly influenced by dietary CP level.
Consequently, the diets containing 18.0 and $19.5 \%$ CP were more effective in improving egg mass production. In addition, the egg mass obtained with the $18.0 \% \mathrm{CP}$ diet was similar to that observed with the $19.5 \% \mathrm{CP}$ diet. According to Rashid et al. (2012), feeding poultry reared in hot climates with high protein levels is not recommended because of the high heat increment resulting from protein digestion. The egg mass results of the present study are in line with those of Azghadi et al. (2014), who did not observe any increase in egg mass of Japanese quails when dietary CP levels were increased from 18 to $22 \%$. In laying chickens, previous observations indicated that increasing dietary CP from 14 to $16 \%$ increased egg mass (Park \& Ryu, 2011).

The reduction $(p<0.05)$ of PER with increasing dietary CP levels may be attributed to higher CP intake (Dos Santos et al. 2016), as high-protein diets increase protein excretion, resulting in lower PER. This result is in agreement with previous findings (Li et al., 2011; Ratriyanto et al., 2014b; Dos Santos et al., 2016).

The 19.5\% CP diet increased EER compared with the $16.5 \%$ CP $(p<0.05)$. Because the birds were fed isocaloric diets, this result is explained by the higher egg mass produced by the birds fed $19.5 \%$ CP.

Table 3 - Production performance of Japanese quails fed diets with varying levels of crude protein and betaine.

\begin{tabular}{|c|c|c|c|c|c|c|c|c|}
\hline Treatments & & $\mathrm{Fl}(\mathrm{g})$ & EP (\%) & EW (g) & EM (g) & FCR & PER & EER \\
\hline \multicolumn{9}{|c|}{ Interaction effects between protein (\%) and betaine (\%) } \\
\hline 16.5 & 0 & 19.08 & 62.77 & 8.45 & 5.25 & 3.60 & 1.69 & 9.95 \\
\hline 16.5 & 0.06 & 20.05 & 71.70 & 8.72 & 6.25 & 3.21 & 1.89 & 11.16 \\
\hline 16.5 & 0.12 & 20.69 & 71.68 & 9.02 & 6.47 & 3.20 & 1.89 & 11.16 \\
\hline 18.0 & 0 & 19.96 & 64.16 & 8.57 & 5.54 & 3.64 & 1.53 & 9.85 \\
\hline 18.0 & 0.06 & 20.80 & 71.92 & 8.84 & 6.38 & 3.28 & 1.70 & 10.91 \\
\hline 18.0 & 0.12 & 20.68 & 75.29 & 9.07 & 6.83 & 3.03 & 1.83 & 11.79 \\
\hline 19.5 & 0 & 19.69 & 66.48 & 8.50 & 5.73 & 3.51 & 1.47 & 10.23 \\
\hline 19.5 & 0.06 & 20.38 & 70.58 & 9.06 & 6.41 & 3.19 & 1.61 & 11.22 \\
\hline 19.5 & 0.12 & 21.28 & 75.77 & 9.09 & 6.83 & 3.09 & 1.66 & 11.56 \\
\hline SEM & & 0.04 & 0.70 & 0.04 & 0.14 & 0.06 & 0.01 & 0.06 \\
\hline$p$ value & & 0.93 & 0.48 & 0.21 & 0.40 & 0.35 & 0.35 & 0.47 \\
\hline \multicolumn{9}{|c|}{ Effects of protein (\%) } \\
\hline 16.5 & & 19.94 & 68.72 & $8.73^{b}$ & $5.99^{b}$ & $3.35^{\mathrm{a}}$ & $1.82^{\mathrm{a}}$ & $10.72^{b}$ \\
\hline 18.0 & & 20.48 & 70.46 & $8.83^{\mathrm{a}}$ & $6.25^{\mathrm{a}}$ & $3.30^{\mathrm{ab}}$ & $1.69^{b}$ & $10.89^{a b}$ \\
\hline 19.5 & & 20.45 & 70.94 & $8.88^{a}$ & $6.34^{\mathrm{a}}$ & $3.24^{b}$ & $1.59^{c}$ & $11.07^{\mathrm{a}}$ \\
\hline SEM & & 0.21 & 0.95 & 0.06 & 0.51 & 0.05 & 0.09 & 0.14 \\
\hline$p$ value & & 0.13 & 0.25 & 0.04 & $<0.01$ & 0.02 & $<0.01$ & 0.03 \\
\hline \multicolumn{9}{|c|}{ Effects of betaine (\%) } \\
\hline 0 & & $19.58^{b}$ & $64.47^{b}$ & $8.51^{\mathrm{a}}$ & $5.51^{c}$ & $3.56^{a}$ & $1.57^{c}$ & $10.01^{c}$ \\
\hline 0.06 & & $20.41^{a}$ & $71.40^{\mathrm{a}}$ & $8.87^{b}$ & $6.35^{b}$ & $3.22^{b}$ & $1.74^{b}$ & $11.10^{\mathrm{b}}$ \\
\hline 0.12 & & $20.89^{a}$ & $74.25^{\mathrm{a}}$ & $9.06^{c}$ & $6.73^{\mathrm{a}}$ & $3.11^{c}$ & $1.80^{a}$ & $11.50^{\mathrm{a}}$ \\
\hline SEM & & 0.38 & 0.89 & 0.16 & 1.27 & 0.14 & 0.07 & 0.43 \\
\hline$p$ value & & $<0.01$ & $<0.01$ & $<0.01$ & $<0.01$ & $<0.01$ & $<0.01$ & $<0.01$ \\
\hline
\end{tabular}

FI: feed intake; EP: egg production; EW: egg weight; EM: egg mass; FCR: feed conversion ratio; PER: protein efficiency ratio; EER: energy efficiency ratio.

$a, b, c$ Means in the same column and treatment with no common superscript differ significantly $(p<0.05)$. 
The dietary supplementation with 0.06 and $0.12 \%$ betaine improved the production performance of quails $(p<0.05)$, which is in accordance with previous observations in laying chickens (Lu \& Zou, 2006; Park et al., 2006; Ezzat et al., 2011; Gudev et al., 2011). Moreover, except for feed intake and egg production, the dietary supplementation with $0.12 \%$ betaine promoted better responses compared with 0.06\% betaine $(p<0.05)$. Compared with the diet with no betaine, the higher feed intakes observed when birds were fed 0.06 and $0.12 \%$ betaine $(p<0.01)$ were correlated with 10.45 and $15.17 \%$ higher egg production, and 4.23 and $6.46 \%$ higher egg weights, respectively.

The performance improvement obtained with the dietary supplementation of betaine has been previously described and may be attributed to its osmotic properties and its role as a methyl group donor (Metzler-Zebeli et al., 2009; Ratriyanto et al., 2009a; Ezzat et al., 2011). Kettunen et al. (2001) observed that betaine increased the length of the small intestine and reduced the crypt:villi ratio of broilers, indicating a larger surface area for nutrient absorption, resulting in better live performance. Moreover, betaine is involved in the synthesis of metabolically-active substances and in protein and energy metabolism (Metzler-Zebeli et al., 2009). This was confirmed by the enhanced PER and EER in this study, indicating better protein and energy utilization. In addition, betaine stimulates the anterior pituitary to secrete follicle-stimulating hormone and luteinizing hormone. These hormones promote follicle growth and ovulation, increasing egg production (Zou \& Feng, 2002; Xing \& Jiang, 2012). Previous observations indicated that betaine supplementation in the diets of laying hens increased egg production (Lu \& Zou, 2006; Ezzat et al., 2011; Gudev et al., 2011) and egg weight (Park et al., 2006), and improved feed conversion ratio (Ezzat et al., 2011). In contrast, Harms \& Russel (2002) did not find any effect of betaine on the performance of laying hens that were fed a diet containing adequate choline and methionine as additional sources of methyl group donors. In addition, Park \& Ryu (2011) showed that $0.06 \%$ betaine supplementation did not affect the performance of laying hens.

\section{Egg Quality}

The interaction between protein levels and betaine supplementation influenced yolk weight (Table 4), but not the other evaluated egg-quality parameters. For the three CP levels, betaine supplementation increased yolk weight $(p<0.01)$. Regardless of CP level, this finding indicates that betaine improved the synthesis of yolk precursors, such as very-low-density lipoproteins and vitellogenin, as described previously by Lu \& Zou (2006).

The diets with 18.0 and $19.5 \%$ CP increased yolk and eggshell weight $(p<0.01)$, compared with the $16.5 \%$ CP diet, and these results may be attributed to higher egg weight in those groups. Akbar et al. (1983) also observed that higher dietary CP levels increased yolk percentage in laying hens. Previous studies showed that increasing dietary CP from 16 to $20 \%$ did not affect albumen, yolk, or eggshell weight (Garcia et al., 2005; Abdel-Azeem, 2011), neither eggshell thickness in quails (Abdel-Azeem, 2011). In addition, Agboola et al. (2016) reported that increasing dietary CP from 18 to $24 \%$ did not affect yolk or albumen weight or eggshell thickness in quails. A similar result was obtained by Muhammad et al. (2016), who observed that dietary CP did not affect yolk or albumen weight in quails.

The observed increase $(p<0.01)$ in the weight of egg components, such as the yolk, albumen, and eggshell with betaine supplementation was correlated with higher egg weight. These results may be attributed to the methyl donor function of betaine, which is involved in protein and energy metabolism (Ratriyanto et al., 2009a). The higher albumen weight when betaine was supplemented suggests an increase in protein synthesis, was in agreement with previous studies showing that betaine supplementation improved protein synthesis (Apicella et al., 2013), which increased albumen weight (Joseph et al., 2000). Moreover, the 4.26 and $5.18 \%$ increases in eggshell weight determined with the supplementation of 0.06 and $0.12 \%$ betaine, respectively, may be due the higher availability of minerals for eggshell formation, which is related to improved CA digestibility. However, eggshell thickness was not affected by betaine supplementation in this study, which was in line with previous observations in laying hens (Park \& Ryu, 2011) and ducks (Awad et al., 2014).

\section{CONCLUSIONS}

Dietary protein levels had minor effects on nutrient digestibility coefficients. The diets containing 18.0 and $19.5 \%$ crude protein promoted similar production performance, which was better than that obtained with the $16.5 \%$ crude protein diet, independently of dietary betaine level. The dietary supplementation of 0.06 and $0.12 \%$ betaine improved nutrient 
Table 4 - Egg quality of Japanese quails fed diets with varying levels of crude protein and betaine.

\begin{tabular}{|c|c|c|c|c|c|}
\hline Treatments & & Yolk Weight (g) & Albumen Weight (g) & Shell Weight (g) & Shell Thickness $(\mathrm{mm})$ \\
\hline \multicolumn{6}{|c|}{ Interaction effects between protein (\%) and betaine (\%) } \\
\hline 16.5 & 0 & $2.52^{c}$ & 5.40 & 0.88 & 0.189 \\
\hline 16.5 & 0.06 & $2.58^{\mathrm{bc}}$ & 5.59 & 0.84 & 0.198 \\
\hline 16.5 & 0.12 & $2.75^{\mathrm{ab}}$ & 5.79 & 0.82 & 0.194 \\
\hline 18.0 & 0 & $2.51^{c}$ & 5.40 & 0.86 & 0.199 \\
\hline 18.0 & 0.06 & $2.76^{\mathrm{ab}}$ & 5.77 & 0.89 & 0.195 \\
\hline 18.0 & 0.12 & $2.84^{a}$ & 5.82 & 0.85 & 0.198 \\
\hline 19.5 & 0 & $2.49^{c}$ & 5.26 & 0.92 & 0.192 \\
\hline 19.5 & 0.06 & $2.83^{a}$ & 5.78 & 0.93 & 0.194 \\
\hline 19.5 & 0.12 & $2.81^{\mathrm{a}}$ & 5.73 & 0.86 & 0.196 \\
\hline SEM & & 0.03 & 0.05 & 0.00 & 0.01 \\
\hline$p$ value & & $<0.01$ & 0.19 & 0.13 & 0.15 \\
\hline \multicolumn{6}{|c|}{ Effects of protein (\%) } \\
\hline 16.5 & & $2.61^{b}$ & 5.59 & $0.85^{b}$ & 0.194 \\
\hline 18.0 & & $2.70^{\mathrm{a}}$ & 5.66 & $0.87^{\mathrm{ab}}$ & 0.197 \\
\hline 19.5 & & $2.71^{\mathrm{a}}$ & 5.59 & $0.91^{\mathrm{a}}$ & 0.194 \\
\hline SEM & & 0.04 & 0.02 & 0.02 & 0.01 \\
\hline$p$ value & & $<0.01$ & 0.56 & $<0.01$ & 0.78 \\
\hline \multicolumn{6}{|c|}{ Effects of betaine (\%) } \\
\hline 0 & & $2.51^{c}$ & $5.35^{b}$ & $0.87^{b}$ & 0.193 \\
\hline 0.06 & & $2.72^{b}$ & $5.71^{c}$ & $0.91^{a}$ & 0.196 \\
\hline 0.12 & & $2.81^{\mathrm{a}}$ & $5.78^{a}$ & $0.91^{\mathrm{a}}$ & 0.196 \\
\hline SEM & & 0.09 & 0.10 & 0.01 & 0.01 \\
\hline$p$ value & & $<0.01$ & $<0.01$ & $<0.01$ & 0.14 \\
\hline
\end{tabular}

a,b,c Means in the same column and treatment with no common superscript differ significantly $(p<0.01)$.

digestibility, production performance and egg quality, independently from dietary protein level. Therefore, the findings of this experiment show that Japanese quails can be fed diets contain $18.0 \%$ crude protein and supplemented with betaine.

\section{ACKNOWLEDGMENTS}

The authors wish to thank the Directorate General for Higher Education of the Republic Indonesia for financial support of this work. We are grateful to J. Haryadi, M.S. Giri, R.A. Setyobudi, S. Kusharini, A.E. Haryanti, S.N. Hikmah, and R.D. Cahyanti for their excellent work during the feeding trial of this study.

\section{REFERENCES}

Abdel-Azeem F. Influence of qualitative feed restriction on reproductive performance of Japanese quail hens. Egyptian Poultry Science Journal 2011;31:883-897.

Agboola AF, Omidiwura BRO, Ologbosere DY, lyayi EA. Determination of crude protein and metabolisable energy of Japanese quail (Coturnix coturnix japonica) during laying period. Journal of World Poultry Research 2016;6(3):131-138

Akbar MK, Gavora JS, Friars GW, Gowe RS. Composition of eggs by commercial size categories: Effects of genetic group, age and diet. Poultry Science 1983;62:925-933.
Amerah AM, Ravindran V. Effect of coccidia challenge and natural betaine supplementation on performance, nutrient utilization, and intestinal lesion scores of broiler chickens fed suboptimal level of dietary methionine. Poultry Science 2015;94:673-680.

AOAC. Official methods of analysis. $15^{\text {th }}$ ed. Arlington: Association of Official Analytical Chemists;1990.

Apicella JM, Lee EC, Bailey BL, Saenz C, Anderson JM, Craig SA, Kraemer WJ, Volek JS, Maresh CM. Betaine supplementation enhances anabolic endocrine and Akt signaling in response to acute bouts of exercise. European Journal of Applied Physiology 2013;113:793-802.

Attia YA, Abd-El-Hamid E, Abedalla AA, Berika MA, Al-Harthi MA, Kucuk $\mathrm{O}$, Sahin K, Abou-Shehema BM. Laying performance, digestibility and plasma hormones in laying hens exposed to chronic heat stress as affected by betaine, vitamin C, and/or vitamin E supplementation. SpringerPlus 2016;5:1619-1631.

Aulrich K, Flachowsky G. Wirksamkeit NSP-spaltender enzyme - in vitro -studien an modellfuttermitteln. Proceedings of the 6th Symposium Vitamine und Zusatzstoffe in der Ernaehrung von Mensch und Tier; 1997 Sep 24-25; Jena (GER): Weimar Kessler GmbH; 1997. p.322-328.

Awad AL, Fahim HN, Ibrahim AF, Beshara MM. Effect of dietary betaine supplementation on productive and reproductive performance of domyati ducks under summer conditions. Egyptian Poultry Science Journal 2014;34:453-474.

Azghadi MA, Kermanshahi H, Golian A. The effect of dietary energy and protein levels on growth performance and antibody responses of offspring of laying Japanese quails. Iranian Journal of Applied Animal Science 2014:4:185-190.

Blem CR. Energy balance. In: Whittow GC, editor. Sturkie's avian physiology. $5^{\text {th }}$ ed. San Diego: Academic Press; 2000. p. 327-341. 
Ratriyanto A, Indreswari R,

Nuhriawangsa AMP
Effects of Dietary Protein Level and Betaine Supplementation on Nutrient Digestibility and Performance of Japanese Quails
Daghir NJ. Nutritional strategies to reduce heat stress in broilers and broiler breeders. Lohmann Information 2009;44:6-15.

Ding Y, Bu X, Zhang N, Li L, Zou X. Effects of metabolizable energy and crude protein levels on laying performance, egg quality and serum biochemical indices of Fengda-1 layers. Animal Nutrition 2016;2:9398.

Dos Santos GC, Garcia EA, Filho JAV, Molino ADB, Pelicia K, Berto DA. Performance of Japanese quails fed diets with low-protein and isoleucine. Acta Scientiarum, Animal Sciences 2016;38:219-225.

El-Husseiny OM, Abo-El-Ella MA, Abd-Elsamee MO, Ab-Elfattah MM. Response of broiler chick performance to dietary betaine and folic acid at different methionine levels. International Journal of Poultry Science 2007;6:515-525

Emamzadeh AN, Yaghobfar A. Evaluation of protein digestibility in canola meals between caecectomised and intact adult cockerels. World Academy of Science, Engineering and Technology 2009;57:113-115.

Ezzat W, Shoeib MS, Mousa SMM, Bealish AMA, Ibrahiem ZA. Impact of betaine, vitamin $C$ and folic acid supplementations to the diet on productive and reproductive performance of Matrouh poultry strain under Egyptian summer condition. Egyptian Poultry Science Journal 2011:31:512-537.

Faria Filho DE, Campos DMB, Alfonso-Torres KA, Vieira BS, Rosa PS, Vaz AM, Macari M, Furlan RL. Protein levels for heat-exposed broilers:performance, nutrients digestibility, and energy and protein metabolism. International Journal of Poultry Science 2007;6:187-194.

Garcia EA, Mendes AA, Pizzolante CC, Saldanha ESPB, Moreira J, Mori C, Pavan AC. Protein, methionine+cystine and lysine levels for Japanese quails during the production phase. Brazilian Journal of Poultry Science 2005;7:11-18.

Gudev D, Popova-Ralcheva S, Yanchev I, Moneva P, Petkov E, Ignatova M. Effect of betaine on egg performance and some blood constituents in laying hens reared indoor under natural summer temperatures and varying levels of air ammonia. Bulgarian Journal of Agricultural Science 2011:17:859-866.

Gunawardana P, Roland DA, Bryant MM. Effect of energy and protein performance, egg components, egg solids, egg quality, and profits in molted Hy-line W-36 hens. Journal of Applied Poultry Research 2008:17:432-439

Hamidi H, Jahanian R, Pourreza J. Effect of dietary betaine on performance, immunocompetence and gut contents osmolarity of broilers challenged with a mixed coccidial infection. Asian Journal of Animal and Veterinary Advances 2010;5:193-201

Harms RH, Russell GB. Betaine does not improve performance of laying hens when the diet contains adequate choline. Poultry Science 2002;81:99-101.

Joseph NS, Robinson FE, Korver DR, Renema RA. Effect of dietary protein intake during the pullet-to-breeder transition period on early egg weight and production in broiler breeders. Poultry Science 2000;79:17901796.

Junqueira MO, de Laurentiz AC, da Silva Filardi R, Rodrigues EA, Casartelli EM. Effects of energy and protein levels on egg quality and performance of laying hens at early second production cycle. Journal of Applied Poultry Research 2006;15:110-115.

Kettunen $\mathrm{H}$, Tiihonen $\mathrm{K}$, Peuranen S, Saarinen MT, Remus JC. Dietary betaine accumulates in the liver and intestinal tissue and stabilizes the intestinal epithelial structure in healthy and coccidia-infected broiler chicks. Comparative Biochemistry and Physiology Part A 2001;130:759769 .
Kettunen $\mathrm{H}$, Peuranen $\mathrm{S}$, Jatila $\mathrm{H}$, Nurminen $\mathrm{P}$, Saarinen $\mathrm{M}$, Apajalahti J. Effect of betaine on the microbiology of the chicken gastrointestinal tract. Proceedings of the $12^{\text {th }}$ European Symposium on Poultry Nutrition; 1999 Aug 15-19; Veldhoven (NL): World's Poultry Science Association; 1999. p 186

Klasing KC, Adler KL, Remus JC, Calvert CC. Dietary betaine increases intraepithelial lymphocytes in the duodenum of coccidian-infected chicks and increases functional properties of phagocytes. The Journal of Nutrition 2002;132(8):2274-2282.

Li F, Zhang LM, Wu XH. Effects of metabolizable energy and balanced protein on egg production, quality, and components of Lohmann Brown laying hens. Journal of Applied Poultry Research 2013;22:3646.

Li YX, Wang YQ, Pang YZ, Li JX, Xie XH, Guo TJ, Li WQ. The effect of crude protein level in diets on laying performance, nutrient digestibility of yellow quails. International Journal of Poultry Science 2011;10:110112

Lu JJ, Zou XT. Effects of adding betaine on laying performance and contents of serum yolk precursors VLDL and VTG in laying hen. Journal of Zhejiang University, Agriculture and Life Science 2006;32:287-291.

Metzler-Zebeli BU, Eklund M, Mosenthin R. Impact of osmoregulatory and methyl donor functions of betaine on intestinal health and performance in poultry. World's Poultry Science Journal 2009;65:419-441.

Muhammad N, Altine S, Abubakar A, Chafe UM, Saulawa LA, Garba MG, Yusuf A. Effect of varying protein levels and preservation methods on egg production performance and internal egg qualities of Japanese quails in a semi-arid environment. European Journal of Basic and Applied Science 2016;3:8-19.

Musa U, Haruna ES, Lombin LH. Quails production in the tropics. Vom (NGR): National Veterinary Research Institute Press; 2008

Nahashon SN, Adefope A, Amenyenu A, Wright D. Effect of varying concentrations of dietary crude protein and metabolizable energy on laying performance of pearl grey guinea fowl hens. Poultry Science 2007:86:1793-1799.

NRC - National Research Council. Nutrient requirements of poultry. 9th ed. Washington: National Academic Press; 1994.

Ohta A, Ohtsuki M, Baba S, Takizawa T, Adachi T, Kimura S. Effects of fructooligosaccharides on the absorption of iron, calcium and magnesium in iron-deficient anaemic rats. Journal of Nutritional Science and Vitaminology 1995;41:281-291.

Omidiwura BRO, Odu O, Agboola AF, Akinbola DD, lyayi EA. Crude protein and energy requirements of Japanese quail (Coturnix coturnix japonica) during rearing period. World Poultry Research 2016;6(2):99-104.

Park JH, Kang CW, Ryu KS. Effects of feeding betaine on performance and blood hormone in laying hens. Korean Journal of Poultry Science 2006;33:323-328

Park JH, Ryu KS. Relationship between dietary protein levels and betaine supplementation in laying hens. Journal of Poultry Science $2011 ; 48: 217-222$

R Core Team. R: a language and environment for statistical computing. Vienna: R Foundation for statistical computing; 2015.

Rao SVR, Raju MVLN, Panda AK, Saharia P, Sunder GS. Effect of supplementing betaine on performance, carcass traits and immune responses in broiler chicken fed diets containing different concentration of methionine. Asian-Australasian Journal of Animal Science 2011;24:662-669. 
Ratriyanto A, Indreswari R, Nuhriawangsa AMP
Effects of Dietary Protein Level and Betaine Supplementation on Nutrient Digestibility and Performance of Japanese Quails
Rashid HOS, Huwaida EEM, Ibrahim AY. Effect of dietary protein level and strain on growth performance of heat stressed broiler chicks. International Journal of Poultry Science 2012;11:649-653.

Ratriyanto A, Indreswari R, Dewanti R, Sofyan A. Nutrient digestibility and protein efficiency ratio in quails (Coturnic coturnix japonica) fed high methionine diet with betaine supplementation. Proceedings of the 4th National Conference on Sustainable Animal Agriculture Development; 2012; Bandung (ID): Faculty of Animal Science, Padjadjaran University; 2012. p.146-150.

Ratriyanto A, Indreswari $\mathrm{R}$, Sunarto. Effects of protein levels and supplementation of methyl group donor on nutrient digestibility and performance of broiler chickens in the tropics. International Journal of Poultry Science 2014a;13:575-581.

Ratriyanto A, Indreswari R, Sunarto. The effect of protein levels and betaine supplementation on digestible nutrient and small intestine characteristic of broilers. Proceedings of the 6th National Conference on Sustainable Animal Agriculture Development. Bandung (ID): Faculty of Animal Science, Padjadjaran University; 2014b. p.1-8.

Ratriyanto A, Mosenthin R, Bauer E, Eklund M. Metabolic, osmoregulatory and nutritional functions of betaine in monogastric animals. AsianAustralasian Journal of Animal Science 2009a;22:1461-1476.

Ratriyanto A, Mosenthin R, Jezierny D, Eklund M. Effect of graded levels of dietary betaine on ileal and total tract nutrient digestibilities and intestinal bacterial metabolites in piglets. Journal of Animal Physiology and Animal Nutrition 2010;94:788-796.
Ratriyanto A, Mosenthin R, Jezierny D, Sauer N, Eklund M. Betaine, organic acids and inulin do not affect ileal and total tract nutrient digestibility or microbial fermentation in piglets. Journal of Animal and Feed Sciences 2009b;18:453-464.

Rosebrough RW, McMurtry JP, Vasilatos-Younken R. Dietary fat and protein interactions in the broiler. Poultry Science 1999;78:992-998.

Soares R. Fonseca JB, Santos AS, Mercandante MB. Protein requirement of Japanese quail (Coturnix coturnix japonica) during rearing and laying periods. Brazilian Journal of Poultry Science 2003;5:153-156.

Suprijatna E, Sunarti D, Mahfudz LJ, Ni'mah U. The efficiency of the use of protein for the egg production in quails fed low protein diet supplemented with lysine synthesis. Proceedings of the National Seminar on Animal Agriculture Development; 2009; Semarang (ID); 2009. p. 648-654.

Tuleun CD, Adenkola AY, Yenle FG. Performance and erythrocyte osmotic membrane stability of laying Japanese quails (Coturnix coturnix japonica) fed varying dietary protein levels in a hot-humid tropics. Agriculture and Biology Journal of North America 2013;4:6-3.

Xing J, Jiang Y. Effect of dietary betaine supplementation on mRNA level of lipogenesis genes and on promoter $\mathrm{CpG}$ methylation of fatty acid synthase (FAS) gene in laying hens. African Journal of Biotechnology 2012;11(24):6633-6640.

Zou XT, Feng J. Effect of betaine on performance of laying hens. Chinese Journal of Animal Science 2002;38:7-9. 
